\title{
Technical and economic viability of biostimulant applied in post-emergence of common bean
}

\section{Viabilidade técnica e econômica de bioestimulante aplicado em pós-emergência de feijão comum}

\author{
Vinicius Cesar Sambatti \\ Universidade Estadual de Londrina \\ E-mail: viniciussambatti@hotmail.com \\ OrclD: https://orcid.org/0000-0001-9546-1114 \\ Hugo Leonardo Lima Gomes \\ Universidade Estadual de Londrina \\ E-mail: hugo.leonardo_@hotmail.com \\ OrclD: https://orcid.org/0000-0002-4749-375X \\ Giliardi Dalazen \\ Universidade Estadual de Londrina \\ E-mail: giliardidalazen@gmail.com \\ OrcID: http://orcid.org/0000-0003-2510-8264
}

\begin{abstract}
The intensification of agricultural production increases the search for management that increases crop productivity, including the use of plant biostimulants. The aim of this study was to evaluate the technical and economic viability of Stimulate ${ }^{\circledR}$ biostimulant, applied at V4 or R5 stages of common bean culture. Two experiments were carried out at different seasons (rainy and dry season) in Londrina, PR, in the 2016/17 agricultural year. The treatments were organized in a factorial scheme $(5 \times 2)$ and consisted of doses of the Stimulate ${ }^{\circledR}$ biostimulant $\left(0 ; 500 ; 1,000 ; 1,500\right.$ and $\left.2,000 \mathrm{~mL} \mathrm{ha}^{-1}\right)$ and phenological stages of the crop at the time of application (V4 and R5). The grain yield and yield components of the crop were evaluated, and an economic analysis was carried out. In the rainy season, the application of the biostimulant at the dose of 500 $\mathrm{mL} \mathrm{ha-1}$ provided the best results, resulting in productivity $226 \mathrm{~kg} \mathrm{ha}^{-1}$ higher than the control, and increased profitability by $6.22 \%$. In the dry season, the highest productivity was also achieved with the application of 500 $\mathrm{mL} \mathrm{ha}^{-1}$, providing a grain yield $39.4 \%$ higher than the control, and an increase of $36.4 \%$ in the profit margin. No differences were observed between the application stages for the grain yield variable. However, for some productivity components, the application in R5 resulted in better results. The rainy season was more productive, with an average yield of $3,630 \mathrm{~kg} \mathrm{ha}^{-1}$, while in the dry season the average was $1,360 \mathrm{~kg} \mathrm{ha}^{-1}$. The use of biostimulant was technically and economically viable when applied at a dose of $500 \mathrm{~mL} \mathrm{ha}^{-1}$ at both common bean stages (V4 or R5) and growing seasons (rainy or dry season).
\end{abstract}

Keywords: Phaseolus vulgaris, Plant regulator, Auxin, Cytokinin, Gibberellin.

Resumo: A intensificação da produção agrícola aumenta a busca por manejos que aumentem a produtividade das culturas, incluindo uso de bioestimulantes vegetais. O objetivo deste trabalho foi avaliar a viabilidade técnica e econômica do bioestimulante Stimulate ${ }^{\circledR}$, aplicado nos estágios V4 ou R5 da cultura do feijão. Dois experimentos foram conduzidos em diferentes épocas (estação das águas e da seca) em Londrina, PR, no ano agrícola de 2016/17. Os tratamentos foram organizados em esquema fatorial (5x2) e consistiram em doses do bioestimulante Stimulate ${ }^{\circledR}\left(0 ; 500 ; 1.000 ; 1.500\right.$ e $\left.2.000 \mathrm{~mL} \mathrm{ha}^{-1}\right)$ e estágios fenológicos da cultura no momento da aplicação (V4 e R5). O rendimento de grãos e os componentes de rendimento da cultura foram avaliados e uma análise econômica foi realizada. Na estação das águas, a aplicação do bioestimulante na dose de $500 \mathrm{~mL} \mathrm{ha}^{-1}$ apresentou os melhores resultados, resultando em produtividade $226 \mathrm{Kg} \mathrm{ha}^{-1}$ superior ao controle e aumento de rentabilidade em $6,22 \%$. Na estação seca, a maior produtividade também foi alcançada com a aplicação de $500 \mathrm{~mL} \mathrm{ha}^{-1}$, proporcionando uma produtividade $39,4 \%$ maior que o controle e um aumento de $36,4 \%$ na margem de lucro. Não foram observadas diferenças entre os estágios de aplicação para a variável rendimento de grãos. No entanto, para alguns componentes de rendimento, a aplicação em R5 resultou em melhores resultados. A estação das 
águas foi mais produtiva, com produtividade média de $3.630 \mathrm{~kg} \mathrm{ha}^{-1}$, enquanto na estação seca a média foi de $1.360 \mathrm{~kg} \mathrm{ha}^{-1}$. O uso do bioestimulante foi técnicamente e economicamente viável quando aplicado na dose de $500 \mathrm{~mL} \mathrm{ha-1} \mathrm{em} \mathrm{ambos} \mathrm{estádios} \mathrm{do} \mathrm{feijão} \mathrm{comum} \mathrm{(V4} \mathrm{ou} \mathrm{R5)} \mathrm{e} \mathrm{épocas} \mathrm{de} \mathrm{cultivo} \mathrm{(estação} \mathrm{das} \mathrm{águas} \mathrm{e} \mathrm{da}$ seca).

Palavras-chave: Phaseolus vulgaris, Regulador vegetal, Auxina, Citocinina, Giberelina.

Data de recebimento: $29 / 04 / 2019$

Data de aprovação: 12/04/2020

DOI: https://doi.org/10.30612/agrarian.v13i50.9753

\section{Introduction}

The common bean (Phaseolus vulgaris) is widely cultivated in Brazil, the country with the third largest grain production in the world, with 3.39 million tons, behind Myanmar and India (CONAB, 2017). In Brazil, this crop can be grown at three times of the year: the first growing season is also called the "rainy season", when beans are sown from August through November; the second growing season is called "dry season" usually goes from mid-February to mid-March; and finally, the third growing season, also called irrigated or winter crop, is sown between April and July. Three harvests are possible due to the cultivars being insensitive to the photoperiod and also to the short crop cycle (BARBOSA \& GONZAGA, 2012). The state of Paraná is the main national producer, with approximately 724.9 thousand tons, summing up the three annual seasons, with a cultivated area of approximately 447.5 thousand ha (CONAB, 2017).

The cultivation of common beans in the state of Paraná becomes more consolidated and technified each year, with an emphasis on increasing productivity through the application of appropriate management techniques. Technification involves genetic improvement of cultivars, plant nutrition, management of pests, diseases and weeds, as well as the better knowledge of the culture's ecophysiology (OLIVEIRA et al., 2015; GUIMARÃES et al., 2017). In addition, new technologies have been developed, such as the use of biostimulants (or plant stimulants), which improve the growth and development of the crop, which may result in increased grain productivity (SANTOS et al., 2013; SHARMA et al., 2014).

Biostimulants originate from mixing two or more plant hormones with other substances, such as amino acids, nutrients and vitamins, as well as macro and/or micronutrients, proteins or even microorganisms (CALVO et al., 2014). When applied to seeds or leaves, they can interfere in processes such as germination, rooting, flowering, fruiting and senescence, promoting physiological changes in crops, which can mitigate the effects of abiotic stresses (Sharma et al., 2014).

Among these products is Stimulate $₫$, composed of indolbutyric acid (auxin), kinetin (cytokinin) and gibberellic acid (gibberellin) (AGROFIT, 2019). Auxin plays a key role in cell elongation by activating the proton pump (ATPase), which promotes acidification of the cell wall and allows the action of hydrolytic enzymes synthesized by the action of gibberellins. In addition, this hormone acts in processes such as cell stretching, division and differentiation, tropisms, formation of root primordia, apical dominance, flowering, flower abscission, and fruit establishment (VANNESTE \& FRIML, 2009). Cytokinins are involved in the regulation of growth and differentiation, including cell division, apical dominance, organ formation, retardation of chlorophyll degradation, development of chloroplasts, leaf senescence, opening and closing of stomata, flower buds and shoot development, metabolism of nutrients and regulation of gene expression (VIEIRA \& MONTEIRO, 2002; OSUGI \& SAKAKIBARA, 2015). Finally, gibberellin promotes germination in some species, overcoming dormancy and acting in both degradation of reserves and mobilization of the endosperm, promoting stem extension of several species, increasing cell division, besides participating in the development of flowers and fruits (HIGASHI et al., 2002).

The use of biostimulants in common bean has shown divergences regarding its efficiency and economic viability. Under some conditions, the application of these products increased grain yield (VIEIRA et al., 2000; CASTRO et al., 2004), while in other studies this effect is not observed (ÁVILA et al., 2010; SILVA et al., 2016), increasing production costs. These variations may be related to the environment, growing season, application stage, dose, cultivars, fertilization, among other factors (ABRANTES, 2011).

Therefore, the aim of this study was to evaluate technical and economic viability of post-emergence application of doses of Stimulate $\circledR$ on common bean, at different growth stages and seasons. 


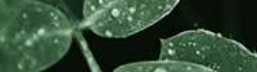

\section{Material and Methods}

\section{Location and characterization of the experimental area}

The experiments (rainy and dry seasons) were conducted in Londrina, PR (23.381 ${ }^{\circ} \mathrm{S} ; 51.233^{\circ} \mathrm{W} ; 595$ $\mathrm{m}$ asl). The soil is classified as Oxisol, with a very clayey texture (SANTOS et al., 2018). In the previous year the area was cultivated with soybeans in summer and oats for soil cover in winter under no-tillage system. Liming was performed one year prior to the implantation of the experiment, raising CEC up to $60 \%$. Soil fertility was measured prior to this study at $0-20 \mathrm{~cm}$ depth, following the methodologies proposed by Pavan et al. (1992) (Table 1).

Table 1. Chemical and physical characteristics of the soil of the experimental area.

\begin{tabular}{|c|c|c|c|c|c|c|c|}
\hline $\mathrm{pH} \mathrm{CaCl}{ }_{2}$ & $\begin{array}{c}\mathbf{P} \\
\text { Melich 1 } \\
\mathrm{mg} \mathrm{dm}^{-3}\end{array}$ & CTC pH7 & CTC effective & $\begin{array}{l}\mathrm{Ca}^{2+} \\
--\mathrm{cmc}\end{array}$ & $\mathrm{Mg}^{2+}$ & $\mathrm{K}^{+}$ & $\mathrm{Al}^{3+}$ \\
\hline 4.51 & 11.07 & 8.98 & 4.53 & 3.19 & 0.95 & 0.26 & 0.13 \\
\hline V\% & $\mathrm{pH} \mathrm{H} \mathrm{H}_{2} \mathrm{O}$ & $\mathrm{H}+\mathrm{Al}$ & $\mathrm{H}^{+}$ & O.M. & Clay & Silt & Sand \\
\hline 49.04 & 5.23 & 4.57 & 4.44 & 2.00 & 75.00 & 15.00 & 10.00 \\
\hline
\end{tabular}

*O.M: organic matter

The climate of the region, according to the Koppen classification, is defined as humid subtropical Cfa. This climate is characterized by hot summers, winters with uncommon frosts and a tendency to concentrate rain in the summer months (NITSCHE et al., 2019). The average temperature during the coldest month is 18 ${ }^{\circ} \mathrm{C}$, and above $22^{\circ} \mathrm{C}$ during the hottest month. Temperatures and rainfall in Londrina-PR during the conduction of the experiments are presented in figures 1 and 2, respectively. The data were obtained at the agrometeorological station of the Agronomic Institute of Paraná (IAPAR), Londrina-PR.
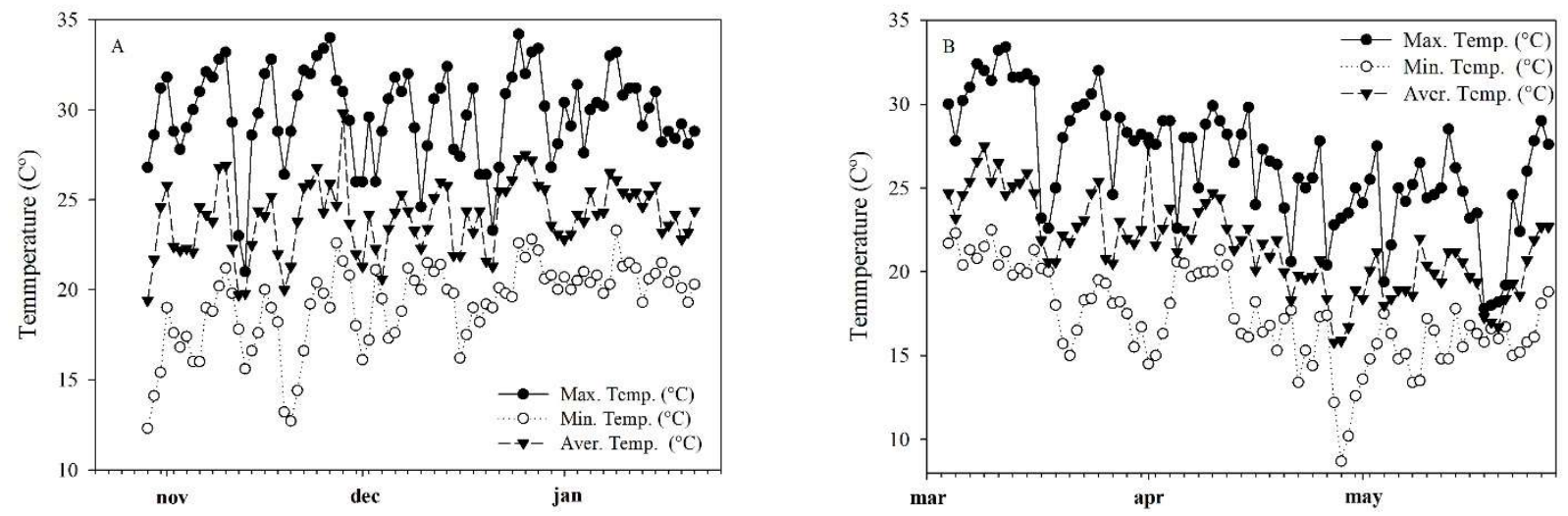

Figure 1. Maximum, average and minimum air temperatures in Londrina-PR during the rainy season $(A)$ and dry season (B).
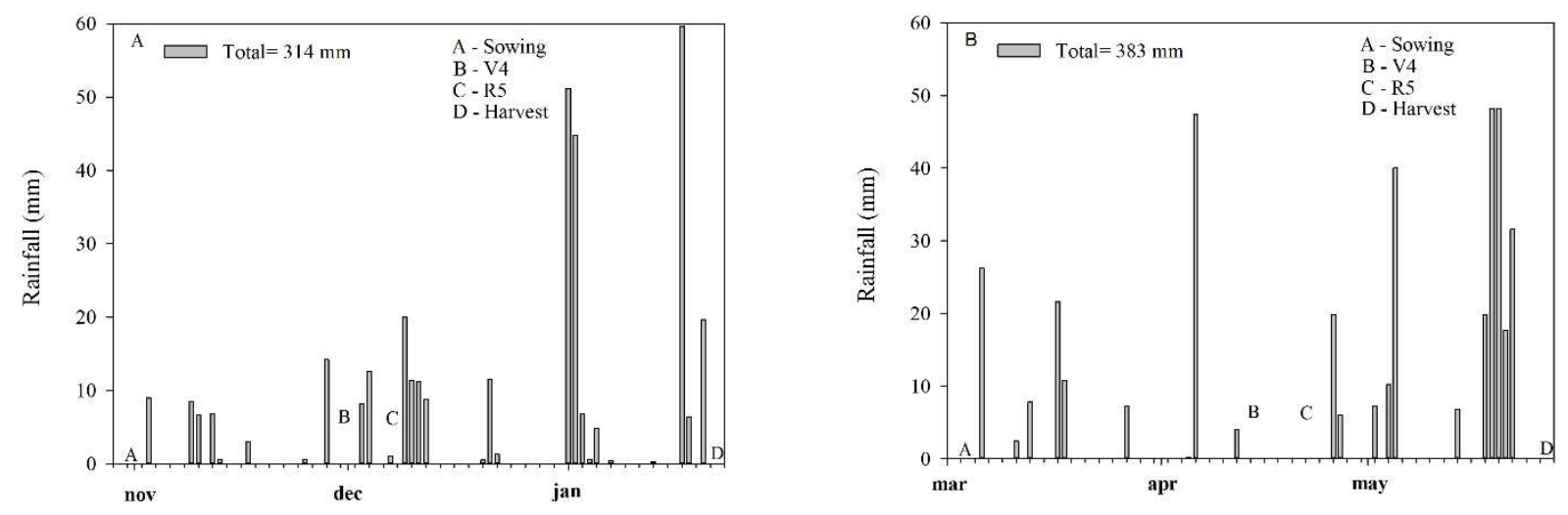
Figure 2. Rainfall in Londrina-PR during the rainy season $(A)$ and dry season $(B)$.

\section{Experimental design and treatments}

Two experiments were carried out in the same experimental area, but at different times: one during the rainy season and the other during the dry season. Both followed the same methodology. Each experiment was arranged as a factorial $5 \times 2$, in a randomized complete block design with four replicates. Each experimental unit consisted of a 12- $\mathrm{m}^{2}$ plot ( $3 \mathrm{~m}$ wide $\times 4 \mathrm{~m}$ long). Treatments were a combination of five doses of the Stimulate ${ }^{\circledR}\left(0 ; 500 ; 1,000 ; 1,500\right.$ and $\left.2,000 \mathrm{~mL} \mathrm{ha}^{-1}\right)$ and two phenological stages at the time of biostimulant application (V4 and R5) (Oliveira et al., 2018). Stimulate ${ }^{\circledR}$ is registered in the Ministry of Agriculture, Livestock and Food Supply being a liquid product formed from the combination of plant regulators, containing kinetin (90 $\left.\mathrm{mg} \mathrm{L}^{-1}\right)$, giberelic acid $\left(50 \mathrm{mg} \mathrm{L}^{-1}\right)$ and 4-indol-3ilbutyric acid $\left(50 \mathrm{mg} \mathrm{L}^{-1}\right)$. The dose recommended by the manufacturer is $500 \mathrm{~mL} \mathrm{ha}^{-1}$ (AGROFIT, 2019).

\section{Implantation and conduction of the experiment}

The area was previously desiccated with glyphosate (Roundup Transorb® - $480 \mathrm{~g}$ a.e. $\mathrm{L}^{-1}, 648 \mathrm{~g} \mathrm{~L}^{-1}$ Isopropylamine salt) at the dose of $1,440 \mathrm{~g}$ a.e. ha-1. Sowing of the rainy season was carried out on October 29th, 2016 and the dry season on March 3rd, 2017. Sowing was performed mechanically, with spacing between rows of $0.45 \mathrm{~m}$ and deposition of 14 seeds per meter, which resulted in seeding density of approximately 311,000 seeds ha ${ }^{-1}$. The cultivar used was IPR Curió, which is characterized by an early cycle. The seeds were treated with the insecticide imidacloprid (Imidacloprid Nortox® - $480 \mathrm{~g}$ a.i. L-1) at a dose of 30 m c.p. $\mathrm{kg}^{-1}$ of seeds, and with the fungicide picoxystrobin + ciproconazole (Aproach Prima ${ }^{\circledR}-200 \mathrm{~g}$ a.i. $\mathrm{L}^{-1}+80$ $\mathrm{g}$ a.i. $\mathrm{L}^{-1}$ ) at a dose of $20 \mathrm{~mL}$ c.p. $\mathrm{kg}^{-1}$ of seeds. At the time of sowing Gelfix $5 \circledR$ inoculant, composed of Bradyrhizobium elkaniibr, at a concentration of $5 \times 109 \mathrm{CFU} \mathrm{mL}-1$ was added at a dose $200 \mathrm{~mL}$ c.p. $100 \mathrm{~kg}^{-1} \mathrm{of}^{-1}$ seeds. Fertilization was carried out with $268 \mathrm{~kg} \mathrm{ha}^{-1}$ of 02-20-18 NPK, according to the demands soil analyses (Table 1). Cover fertilization consisted of $40 \mathrm{~kg} \mathrm{ha}^{-1}$ of nitrogen via urea (46\% of nitrogen) at the phenological stage V3, distributed on the soil surface.

Due to low infestation, weed control during the crop cycle was performed manually. Since the occurrence of diseases at control levels was not observed, an application of the fungicide picoxystrobin + ciproconazole (Aproach Prima ${ }^{\circledR}, 200 \mathrm{~g}$ a.i. $\mathrm{L}^{-1}+80 \mathrm{~g}$ a.i. $\mathrm{L}^{-1}$ ) was carried out in a preventive manner, at a dose of $300 \mathrm{~mL}$ c.p. ha ${ }^{-1}$ at the phenological stage R5. Periodic monitoring did not detect the occurrence of pest insects at the control level and, therefore, no application of insecticide was carried out.

\section{Application of treatments}

In the phenological stages V4 and R5, foliar applications of the biostimulant were carried out in the morning with a constant pressure sprayer pressurized by $\mathrm{CO}_{2}$, equipped with a 3-m bar, with six TeeJet 11002 nozzles, spaced every $0.5 \mathrm{~m}$. At the time of the application, the bar was maintained $0.5 \mathrm{~m}$ above the crop canopy. The spraying was carried out with a pressure of 30 psi and speed of $1 \mathrm{~m} \mathrm{~s}^{-1}$, dispensing a spray volume equivalent to $200 \mathrm{~L} \mathrm{ha}^{-1}$.

\section{Variables evaluated}

The rainy season experiment was harvested on Jan 21st 2017, and the dry season on May 27th 2017, after the physiological maturation of the crop. At these times, an area of $2.25 \mathrm{~m}^{2}$ per plot $(2 \mathrm{~m}$ from the two central lines) was harvested to determine grain yield $\left(\mathrm{kg} \mathrm{ha}^{-1}\right)$ and mass of 1,000 grains (MTG). Both were calculated by adjusting for $13 \%$ moisture content. Within each plot, 10 plants were randomly collected for the evaluations of number of pods per plant (NPP), number of locules per pod (NLP), and number of grains per pod (NGP).

\section{Statistical analysis of data}

The data of each experiment were separately submitted to analysis of variance (ANOVA) (test $F, p$ $<0.05)$ with the aid of the statistical program Assistat. The complementary analysis was performed by adjusting 
nonlinear regressions, according to the significance of the equations provided by the statistical program. So, second- or third-degree regressions were adjusted using the Sigmaplot 12.0 statistical program.

\section{Economic viability analysis}

In order to carry out the economic viability analysis of the use of the biostimulant, operating costs of $R \$$ $40.00 \mathrm{ha}^{-1}$ were taken, according to data from the ABC Fundation, and cost of $R \$ 100.00 \mathrm{~L}^{-1}$ of commercial product Stimulate $\AA$, based on consultation held in agricultural stores in Londrina-PR. The price per $\mathrm{kg}$ of common bean was determined from the average prices of the years 2015, 2016, 2017 and 2018, according to the Department of Rural Economy - DERAL of the State of Paraná, reaching the price of $R \$ 2,43 \mathrm{~kg}^{-1}$.

\section{Results and Discussion}

\section{Grain yield}

There was a large difference between the means of grain yield obtained at different crop seasons (Figure 3). In the rainy harvest the average grain yield reached around 3,400 to $4,000 \mathrm{~kg} \mathrm{ha}^{-1}$. In the dry season the yields were around 1,000 to $1,800 \mathrm{~kg} \mathrm{ha}^{-1}$. The variation in productivity of the rainy for the dry season can be explained by the lower temperatures to which the crop was submitted in the dry season. At this season, the temperature reached a minimum of 10 to $15^{\circ} \mathrm{C}$ (Figure 1), being $5^{\circ} \mathrm{C}$ cooler than rainy season. This temperature is considered low, since the optimal range for common bean development is 17 to $25^{\circ} \mathrm{C}$, with an optimal value of $21^{\circ} \mathrm{C}$ (BARBOSA \& GONZAGA, 2012). Another factor that may explain this difference in grain yield among the different growing seasons is the distribution of rainfall, especially during the flowering period, which is considered critical for high yields (Figures $2 \mathrm{~A}$ and $2 \mathrm{~B}$ ).

Significance was observed for the dose in the rainy season $(p<0.05)$ and dry season $(p<0.001)$ (Table 2). However, there was no difference between the phenological stages at the time of application in both growing seasons.

Table 2. Summary of the variance analysis (mean squares) for evaluations of grain yield and yield

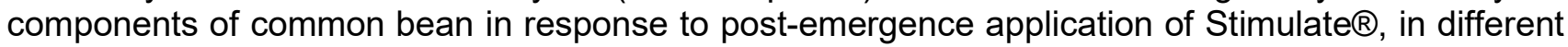
doses and application stages in rainy and dry seasons.

\begin{tabular}{|c|c|c|c|c|c|c|}
\hline \multicolumn{7}{|c|}{ Rainy season } \\
\hline & \multicolumn{6}{|c|}{ Mean squares } \\
\hline SV & DF & Yield & NPP & MTG & NLP & NGP \\
\hline Application stage (AS) & 1 & $1071252.90^{\mathrm{ns}}$ & $235.23^{* *}$ & $328.33^{\text {ns }}$ & $0.756^{* *}$ & $0.84^{* *}$ \\
\hline Dose (D) & 4 & $143200.85^{*}$ & $186.16^{* *}$ & $99.17^{\mathrm{ns}}$ & $1.52^{\star *}$ & $1.42^{* *}$ \\
\hline$A S \times D$ & 4 & $123210.90^{n s}$ & $28.81^{\star *}$ & $50.00^{\text {ns }}$ & $0.18^{\text {ns }}$ & $0.13^{*}$ \\
\hline Mean & & 3630.83 & 37.04 & 263.67 & 5.80 & 5.64 \\
\hline CV (\%) & & 6.31 & 6.04 & 3.49 & 4.85 & 3.64 \\
\hline \multicolumn{7}{|c|}{ Dry season } \\
\hline & \multicolumn{6}{|c|}{ Mean squares } \\
\hline SV & DF & Yield & NPP & MTG & NLP & NGP \\
\hline Application stage (AS) & 1 & $53728.9^{\text {ns }}$ & $0.02^{\mathrm{ns}}$ & $17.16^{\mathrm{ns}}$ & $0.68^{*}$ & $0.53^{\mathrm{ns}}$ \\
\hline Dose (D) & 4 & $388382.81^{* *}$ & $38.59^{* *}$ & $395.75^{\text {ns }}$ & $0.76^{\star \star}$ & $0.90^{* *}$ \\
\hline$A S \times D$ & 4 & $14803.84^{\mathrm{ns}}$ & $36.47^{\star *}$ & $93.60^{\mathrm{ns}}$ & $0.13^{\text {ns }}$ & $0.15^{\mathrm{ns}}$ \\
\hline Mean & & 1360.50 & 20.30 & 192.83 & 6.51 & 5.67 \\
\hline CV (\%) & & 17.55 & 4.11 & 6.25 & 5.41 & 7.88 \\
\hline
\end{tabular}

${ }^{* *}$ significant at the $1 \%$ probability level $(p<0.01)$; ${ }^{*}$ significant at the $5 \%$ probability level $(p<0.05)$; ${ }^{\text {ns }}$ not significant $(p>0.05)$. SV: Source of variation; DF: Degrees of freedom; NPP: Number of pods per plant; MTG: mass of a thousand grains; NLP: Number of locules per pod; NGP: number of grains per pod.

In the rainy season, the dose that generated the highest absolute values of grain yield was that recommended $\left(500 \mathrm{~mL} \mathrm{ha}^{-1}\right)$, regardless of the phenological stage of application (Figure 3 ). When the biostimulant was applied at $500 \mathrm{~mL} \mathrm{ha}^{-1}$, grain yield was $3,855 \mathrm{~kg} \mathrm{ha}^{-1}$. In contrast, in the control treatment the grain yield was $3,629 \mathrm{Kg} \mathrm{ha}^{-1}$, or $6.22 \%$ lower in relation to the best evaluated dose. For the other doses, the grain yield was equal to that obtained in the control plot. 
Similarly, in the dry season the best dose was also $500 \mathrm{~mL} \mathrm{ha}^{-1}$, at both phenological stages evaluated (Figure 3). The application of this dose resulted in an average grain yield of $1,712 \mathrm{~kg}^{-1}$, about $39.41 \%$ higher than the control treatment, which produced only $1,228 \mathrm{~kg} \mathrm{ha}^{-1}$.

In a similar study it was verified that the best phenological stage for the application of biostimulant in common bean is during the R5 to R7 phase (COBUCCl et al., 2008). However, in the present study, there was no difference between application at the phenological stages V4 and R5. Similarly to the results obtained, in an experiment carried out by Rossi (2011), analyzing the influence of Stimulate $₫$ doses of 500 and $1000 \mathrm{~mL}$ ha $^{-1}$ in a single application at V4 or parceled ( $1 / 2$ dose at V4 and $1 / 2$ dose at R5), it was observed that there was a significant influence of the application of the product on the common bean grain yield and yield components. At the dose of $500 \mathrm{~mL} \mathrm{ha}^{-1}$, the best results were obtained, both in single application and in parceled application.

In the rainy season, it was observed that doses higher than $500 \mathrm{~mL} \mathrm{ha}^{-1}$ resulted in grain yields equal to or even lower than that obtained in the control treatment (Figure 3). Although there were no statistical differences between the stages, lower productivity is observed when higher doses and application in V4 are associated. This fact can be explained by the greater vegetative growth to the detriment of the development of plant reproductive structures caused by hormonal and/or physiological effects. Unlike works carried out in different periods and in different locations, where it was found that the applications carried out at R5 stage had a positive effect on the yield and on the yield components compared to the control, but this effect was not observed at V4 application (COBUCCl et al., 2008). Santos et al. (2014) found that growth regulators are one of the most active factors for the production of dry mass in the vegetative phase of the plant until complete flowering, but they can cause a hormonal imbalance, hindering the formation of reproductive structures in the plant and, consequently, have a negative effect on crop grain yield.

Thus, only the application of $500 \mathrm{~mL} \mathrm{ha}^{-1}$ at V4 or R5 stages provided improvements in the crop grain yield in both growing seasons (Figure 3). On the other hand, increasing the dose caused a reduction in grain yield. After a certain dose, the physiological effects can occur negatively and impair the development of plants (ÁVILA et al., 2010; BOSSOLANI et al., 2017).

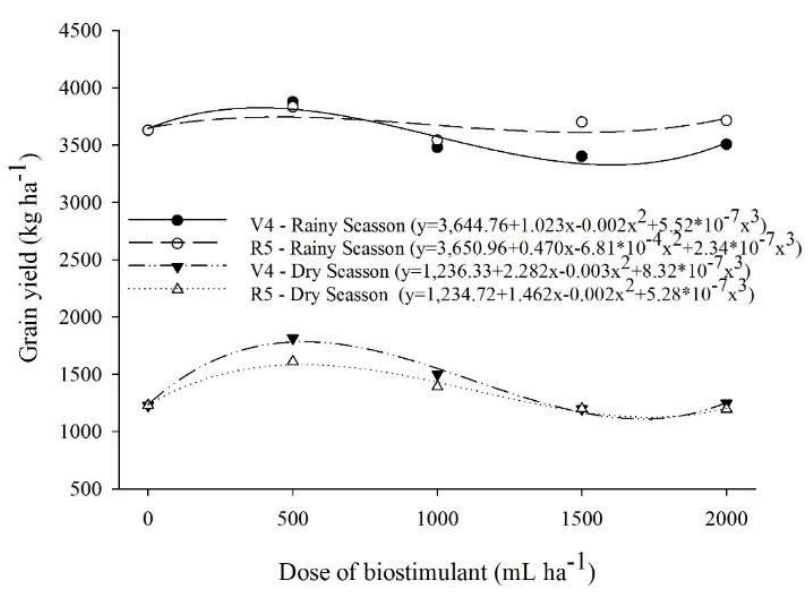

Figure 3. Grain yield of common bean in response to the doses of biostimulant applied at different phenological stages (V4 and R5) in the rainy and dry seasons.

\section{Number of pods per plant (NPP)}

The application of biostimulant resulted in variable responses in NPP, according to the dose and application stage interaction (Table 2). In the rainy season (Figure 4A), the highest NPP was observed with the application of $500 \mathrm{~mL} \mathrm{ha-1}$ at R5 stage (44.8 pods per plant). The application of any dose of biostimulant at R5 provided an increase in NPP compared to the control treatment (13.26 pods per plant). For application at V4, there was a tendency to increase NPP with the increase in the dose of biostimulant, with maximum values reached in the dose of $2,000 \mathrm{~mL} \mathrm{ha}^{-1}$. However, the application of this dose at V4 did not exceed the NNP obtained by the recommended dose $\left(500 \mathrm{~mL} \mathrm{ha}^{-1}\right)$ applied at R5. Regardless of the dose, the best results were obtained when the application occurred at R5 stage (Figure 4A) 
In the dry season (Figure 4B and Table 2), the highest NPPs were observed with the application of 500 $\mathrm{mL} \mathrm{ha}^{-1}$ at V4 stage (23.85 pods per plant), where the adjustment showed its maximum point, followed by a decrease. Already at R5, the doses of 1,500 and $2,000 \mathrm{~mL} \mathrm{ha}^{-1}$ resulted in higher NPP values compared to the control treatment (5.4 pods per plant) and other doses. Overdose applications can decrease the beneficial results, as well as the study developed by Bossolani et al. (2017). In the dry season, the phenological stage was significantly different and variable according to the doses (Figure 4B). The dose of $500 \mathrm{~mL} \mathrm{ha}^{-1}$ was better when applied at V4. The doses of 1500 and $2000 \mathrm{~mL} \mathrm{ha}^{-1}$ had higher NPP when applied at R5 stage.
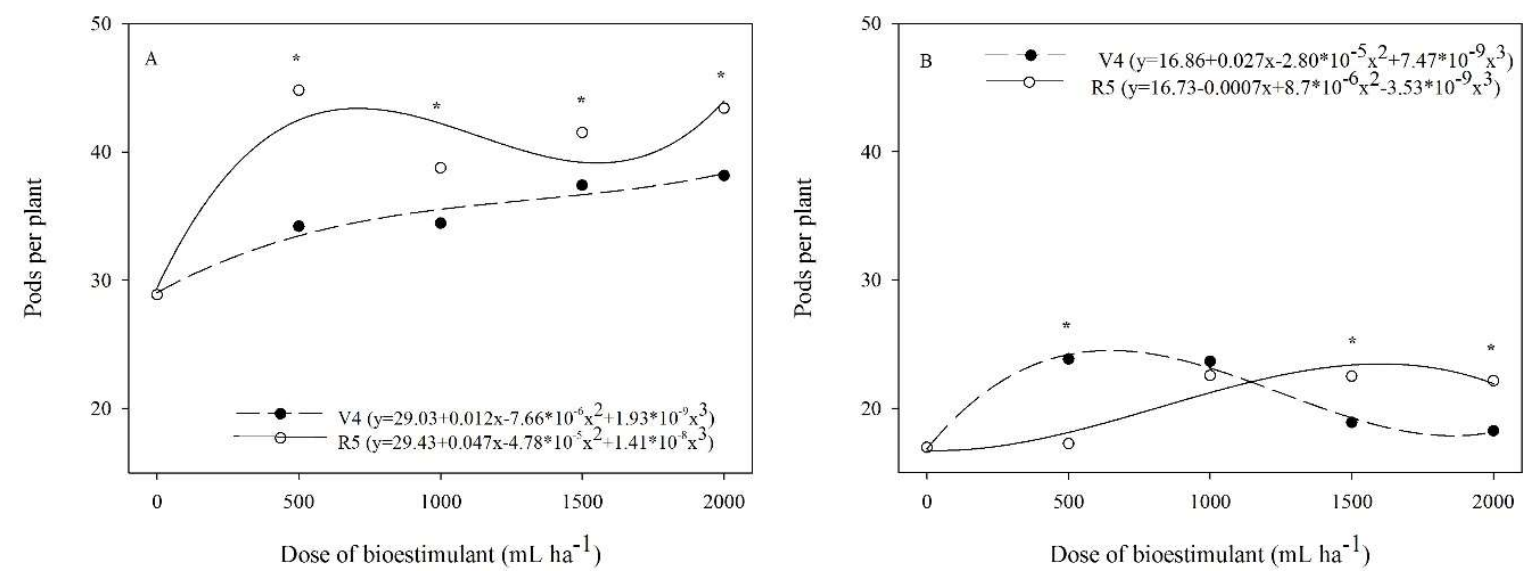

Figure 4. Number of pods per plant in response to doses of biostimulant applied at different phenological stages (V4 and R5) in the rainy season (A) and in the dry season (B). * Significant difference between the phenological stages within the same dose of biostimulant.

\section{Mass of thousand grains (MTG)}

There was no significances for the sources of variation for the variable mass of a thousand grains (MTG) (Table 2). The average MTG value for the rainy season was $263.67 \mathrm{~g}$. On the other hand, in the dry season the MTG value was lower, with an average value of $192.83 \mathrm{~g}$ (Figure 5).
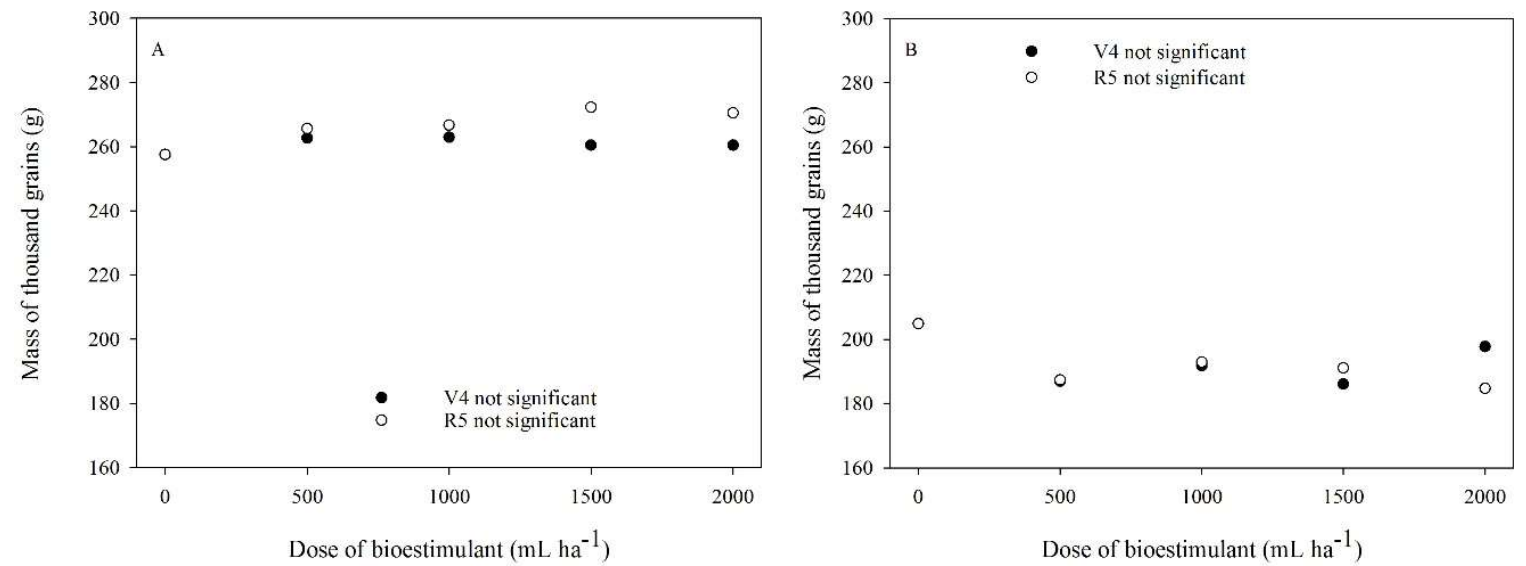

Figure 5. Mass of thousand grains (MTG) in response to doses of biostimulant applied at different phenological stages (V4 and R5) in the rainy season (A) and in the dry season (B).

The effect of biostimulants on MTG of common bean is quite controversial. For example, Cobucci et al. (2008) found higher MTG when the biostimulant was applied. However, Abrantes et al. (2011) and Bossolani et al. (2017) did not observe differences for this variable with the application of biostimulant. This variation in the results may be due to several factors that can influence the efficiency and action (VIEIRA \& MONTEIRO, 2002).

\section{Number of locules per pod (NLP)}


The phenological stage of biostimulant application was significant in the rainy season $(p<0.01)$ and in the dry season $(p<0.05)$. In both growing seasons the application at R5 stage provided the best results for the NLP (Figure 6). In addition, the effect of dose was significant in both seasons (Table 2). In the rainy season (Figure 6A), for application in V4, all doses resulted in NLP higher than the control (5 locules per pod), but they did not differ, with an average of 5.8. For the application at R5 stage, the doses of 500 (NLP=6.35), 1,500 $(\mathrm{NLP}=6.4)$ and $2,000(\mathrm{NLP}=6.1) \mathrm{mL}^{-1}$ havided NLP higher than the dose of $1,000 \mathrm{~mL} \mathrm{ha}^{-1}$ and the control $(\mathrm{NLP}=5)$. In the dry season, with application at $\mathrm{V} 4$, the greater NLP was obtained by $2,000 \mathrm{~mL} \mathrm{ha}^{-1}$, while the dose of $500 \mathrm{~mL} \mathrm{ha}^{-1}$ provided the worst result, with NLP equal to 5.85 .
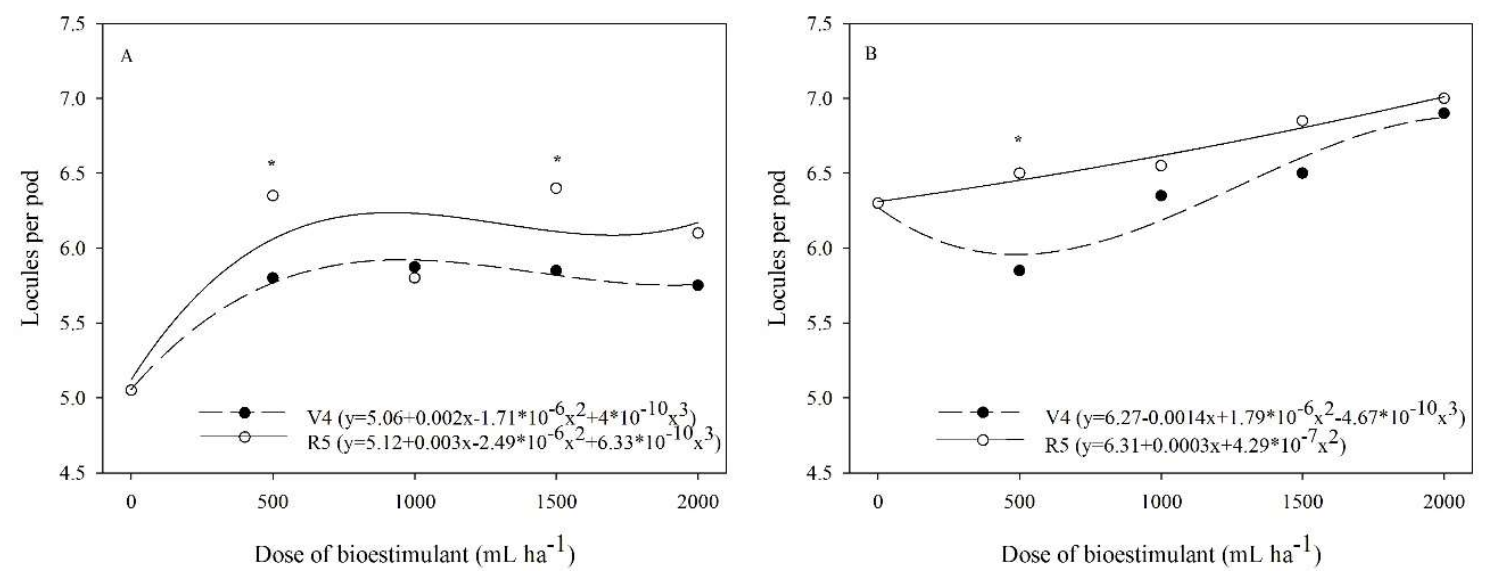

Figure 6. Number of locules per pod (NLP) in response to doses of biostimulant applied at different phenological stages (V4 and R5) in the rainy season (A) and in the dry season (B). * Significant difference between the phenological stages within the same dose of biostimulant.

\section{Number of grains per pod (NGP)}

As for the main factors, significance $(p<0.05)$ was observed for the interaction between the application stage and dose of biostimulant only in the rainy season. In the dry season, only the dose was significant (Table 2). In the rainy season, the application of the biostimulant at both stages resulted in an increase in NGP for all doses when compared to the control ( 0.92 grains per pod). However, the application at R5 generated higher NGP in doses of $500,1,500$ and $2,000 \mathrm{~mL} \mathrm{ha}^{-1}$, with values of 6.1 grains per pod (Figure 7A). When applied at V4, the highest NGP was observed in the dose of $1,500 \mathrm{~mL} \mathrm{ha}^{-1}$ (NGP= 5.8), with all doses being higher than the control $(\mathrm{NGP}=4.9)$, with the presence of a maximum point in the adjustment between the doses of 1,000 and $1,500 \mathrm{~mL} \mathrm{ha}^{-1}$.

In the dry season (Figure 7B), the best results were obtained with the application at R5 stage of 1,000 and 2,000 $\mathrm{mL} \mathrm{ha}^{-1}$. According to the adjustment obtained, V4 applications required doses between 1,000 and $1,500 \mathrm{~mL} \mathrm{ha}^{-1}$ to increase NGP, tending to increase up to a dose of $2,000 \mathrm{~mL} \mathrm{ha}^{-1}$.

Thus, application at R5 stage resulted in a greater number of grains per legume. This effect can be attributed to the action of auxins, which palys an important role in delaying floral abscission and stimulating floral adhesion without fertilization (Andrei, 2005). On the other hand, as with the other yield components, V4 applications stimulate vegetative growth at the expense of the development of reproductive organs, such as pods and grains (Santos et al., 2014). 



Figure 7. Number of grains per pod (NGP) in response to doses of biostimulant applied at different phenological stages (V4 and R5) in the rainy season (A) and in the dry season (B). * Significant difference between the phenological stages within the same dose of biostimulant.

\section{Analysis of the economic viability of biostimulant use}

Despite the differences in grain productivity, it is important to carry out an economic analysis of the use of the biostimulant. In addition to the cost with the biostimulant itself, which increases according to the dose, consideration should be given to the operational cost. In the rainy season (Table 3), the application of the biostimulant at $\mathrm{V} 4$ stage caused a reduction in the relative profit margin when applied at doses equal to or greater than $1,000 \mathrm{~mL} \mathrm{ha-1}$. In this season and application stage, the use of $500 \mathrm{~mL}^{-1}$ generated a relative margin of $105.81 \%$ in relation to the control. When the application was performed at R5, the best result was also obtained in the dose of $500 \mathrm{~mL} \mathrm{ha}^{-1}$, with a relative margin of $104.59 \%$ in relation to the control. These close margins were expected, since the application stage had no significant effect on productivity (Table 2).

Table 3. Analysis of the economic viability of the use of biostimulant in commom bean crop in the rainy season.

\begin{tabular}{|c|c|c|c|c|c|c|}
\hline $\begin{array}{l}\text { Dose } \\
\mathrm{mL} \text { ha } \\
1\end{array}$ & $\begin{array}{c}\text { Application } \\
\text { cost } \\
\mathbf{R} \$ \mathrm{ha}^{-1 *}\end{array}$ & $\begin{array}{l}\text { Grain Yield } \\
\text { kg ha }^{-1}\end{array}$ & $\begin{array}{c}\text { Relative } \\
\text { grain yield \% }\end{array}$ & $\begin{array}{l}\text { Production value } \\
\qquad \mathrm{R} \$ \mathrm{ha}^{-1 * *}\end{array}$ & $\begin{array}{l}\text { Margin } \\
R \$ h^{-1}\end{array}$ & $\begin{array}{c}\text { Relative } \\
\text { margin \% }\end{array}$ \\
\hline \multicolumn{7}{|c|}{ Application at V4 } \\
\hline 0 & 0 & $3,629.00$ & 100.00 & $8,818.47$ & $8,818.47$ & 100.00 \\
\hline 500 & 90.00 & $3,876.75$ & 106.83 & $9,420.50$ & $9,330.50$ & 105.81 \\
\hline 1,000 & 140.00 & $3,478.75$ & 95.86 & $8,453.36$ & $8,313.36$ & 94.27 \\
\hline 1,500 & 190.00 & $3,401.00$ & 93.72 & $8,264.43$ & $8,074.43$ & 91.56 \\
\hline 2,000 & 240.00 & $3,506.25$ & 96.62 & $8,520.19$ & $8,280.19$ & 93.90 \\
\hline \multicolumn{7}{|c|}{ Application at R5 } \\
\hline 0 & 0 & $3,629.00$ & 100.00 & $8,818.47$ & $8,818.47$ & 100.00 \\
\hline 500 & 90.00 & $3,832.75$ & 105.61 & $9,313.58$ & $9,223.58$ & 104.59 \\
\hline 1,000 & 140.00 & $3,541.75$ & 97.60 & $8,606.45$ & $8,466.45$ & 96.01 \\
\hline 1,500 & 190.00 & $3,699.75$ & 101.95 & $8,990.39$ & $8,800.39$ & 99.80 \\
\hline 2,000 & 240.00 & $3,713.25$ & 102.32 & $9,023.20$ & $8,738.20$ & 99.60 \\
\hline
\end{tabular}

* Operational cost of $\mathrm{R} \$ 40.00 \mathrm{ha}^{-1}$ (ABC Foundation) and cost of $\mathrm{R} \$ 100.00 \mathrm{~L}^{-1}$ for Stimulate $\AA$ (consultation held in agricultural stores in Londrina-PR). ${ }^{* *}$ To determine the value of production, the value of $\mathrm{R} \$ 2.43$ per $\mathrm{kg}$ of common bean (DERAL-PR average for the years 2015, 2016, 2017 and 2018) was applied.

In the dry season (Table 4), at V4 application, the doses of $500,1000 \mathrm{~mL} \mathrm{ha}^{-1}$ generated positive relative margins, reaching $144.72 \%$ in the recommended dose. The application of the biostimulant at R5 stage, in the doses of 500 and $1,000 \mathrm{~mL}$ ha-1, results in an economic profitability superior to that of the control, reaching $128.07 \%$ in the recommended dose $\left(500 \mathrm{~mL} \mathrm{ha}^{-1}\right)$. 
Table 4. Analysis of the economic viability of the use of biostimulant in commom bean crop in the dry season.

\begin{tabular}{|c|c|c|c|c|c|c|}
\hline $\begin{array}{l}\text { Dose } \\
\mathrm{mL} \text { ha- } \\
1\end{array}$ & $\begin{array}{c}\text { Application } \\
\text { cost } \\
\mathrm{R} \$ \mathrm{ha}^{-1 *}\end{array}$ & $\begin{array}{l}\text { Grain Yield } \\
\text { kg ha-1 }^{-1}\end{array}$ & $\begin{array}{c}\text { Relative grain } \\
\text { yield \% }\end{array}$ & $\begin{array}{l}\text { Production value } \\
\qquad \$ h^{-1 * *}\end{array}$ & $\begin{array}{l}\text { Margin } \\
R \$ \text { ha }^{-1}\end{array}$ & $\begin{array}{l}\text { Relative } \\
\text { margin \% }\end{array}$ \\
\hline \multicolumn{7}{|c|}{ Application at V4 } \\
\hline 0 & 0 & $1,228.00$ & 100.00 & $2,984.04$ & $2,984.04$ & 100.00 \\
\hline 500 & 90.00 & $1,814.25$ & 147.74 & $4,408.63$ & $4,318.63$ & 144.72 \\
\hline 1.000 & 140.00 & $1,499.25$ & 122.09 & $3,643.18$ & $3,503.18$ & 117.40 \\
\hline 1.500 & 190.00 & $1,198.50$ & 97.60 & $2,912.36$ & $2,722.36$ & 91.23 \\
\hline 2.000 & 240.00 & $1,245.50$ & 101.43 & $3,026.57$ & $2,788.57$ & 93.38 \\
\hline \multicolumn{7}{|c|}{ Application at R5 } \\
\hline 0 & 0 & $1,228.00$ & 100.00 & $2,984.04$ & $2,984.04$ & 100.00 \\
\hline 500 & 90.00 & $1,609.75$ & 131.09 & $3,911.69$ & $3,821.69$ & 128.07 \\
\hline 1.000 & 140.00 & $1,389.25$ & 113.13 & $3,375.88$ & $3,235.88$ & 108.44 \\
\hline 1.500 & 190.00 & $1,197.50$ & 97.52 & $2,909.93$ & $2,719.93$ & 91.15 \\
\hline 2.000 & 240.00 & $1,195.00$ & 97.31 & $2,903.85$ & $2,663.85$ & 89.27 \\
\hline
\end{tabular}

* Operational cost of $\mathrm{R} \$ 40.00 \mathrm{ha}^{-1}$ (ABC Foundation) and cost of $\mathrm{R} \$ 100.00 \mathrm{~L}^{-1}$ for Stimulate $\AA$ (consultation held in agricultural stores in Londrina-PR). ${ }^{* *}$ To determine the value of production, the value of $\mathrm{R} \$ 2.43$ per $\mathrm{kg}$ of common bean (DERAL-PR average for the years 2015, 2016, 2017 and 2018) was considered.

Therefore, it can be stated that the application of the biostimulant was more profitable when used at the dose of $500 \mathrm{~mL} \mathrm{ha-1}$ in both rainy and dry season seasons. Doses above $500 \mathrm{~mL} \mathrm{ha}^{-1}$, in addition to reducing grain yield, increase product costs, reducing crop profitability.

\section{Conclusions}

The use of Stimulate $\circledR$ is technically and economically feasible, in both rainy and dry seasons. The best technical and economic responses for the application of Stimulate ${ }^{\circledR}$ occurs with the dose of $500 \mathrm{~mL} \mathrm{ha}^{-1}$, regardless of the stage of application (V4 or R5). However, even without having an effect on grain yield, the application in R5 increases some yield components of common bean culture.

\section{References}

ABRANTES, F.L.; SÁ, M.E.; SOUZA, L.C.D.; SILVA, M.P.; SIMIDU, H.M.; ANDREOTTI, M.; BUZETTI, S.; VALÉRIO FILHO, W.V.; ARRUDA, N. Use of growth regulator in winter bean cultivars. Pesquisa Agropecuária Tropical, v.41, p.148-154, 2011.

ANDREI, E. Compêndio de defensivos agrícolas: guia prático de produtos fitossanitários para uso agrícola. 7. Ed. São Paulo: Organizações Andrei, 2005 p. 1132.

ÁVILA, M.R.; BARIZÃO, D.A.O.; GOMES, E.P.; FEDRI, G.; ALBRECHT, L.P. Bean cultivation in autumn/winter associated with an application of biostimulant and foliar fertilizer in the presence and absence of irrigation. Scientia Agraria, v. 11, n. 3, p. 221-230, 2010.

BARBOSA, F.R.; GONZAGA, A. C.O. Informações técnicas para o cultivo do feijoeiro-comum na Região Central-Brasileira: 2012-2014. Santo Antônio de Goiás, GO: Embrapa Arroz e Feijão. 2012. 247p. (Embrapa Arroz e Feijão. Documentos, 272).

BOSSOLANI, J.W.; EUSTÁQUIO DE SÁ, M.; MERLOTI, L.F.; BETTIOL, J.V.T.; FONSECA DE OLIVEIRA, G. R.; PEREIRA, D. S. Plant biostimulant associated with a resistance inducer in the production components of the common bean. Revista Agro@mbiente OnLine, v.11, n.4, p. 307-314, 2017.

CALVO, P.; NELSON, L.; KLOEPPER, J.W. Agricultural uses of plant biostimulants. Plant and Soil, The Hague, v. 383, n. 1/2, p. 3-41, 2014.

CASTRO, P.R.C.; SILVA, G.P.; CATO, S.C.; TAVARES, S. Action of biostimulants in bean (Phaseolus vulgaris L. CV. IAC - Carioca Tybatã). Revista da Agricultura, v. 79, n.2, p.215-226, 2004. 
COBUCCI, T.; NASCENTE, S.A.; PEREIRA FILHO, R.C.; MACHADO, A.A.; OLIVEIRA, B.G.K.; CARVALHO, A.B.A. Efeitos de reguladores vegetais aplicados em diferentes estádios de desenvolvimento do feijoeiro comum. Campinas: IAC, 2008. (Documentos, 85).

CONAB. Companhia Nacional de Abastecimento. Acompanhamento da Safra Brasileira de Grãos - Safra 2016/17 - Décimo segundo levantamento. Brasília, DF: CONAB, 2017. v.4, n.12.

GUIMARÃES, R.A.M.; BRAZ, A.J.B.P.; SIMON, G.A.; FERREIRA, C.J.B.; BRAZ, G.B.P.; SILVEIRA, P.M. Response of common bean cultivars to nitrogen fertilization in different phenological stages. Global Science and Technology, v.10, n.01, p.136-148, 2017.

HIGASHI, E.N.; SILVEIRA, R.L.V.A.; GOUVÊA, C.F.; BASSO, L.H. Ação fisiológica de hormônios vegetais na condição hídrica, metabolismo e nutrição mineral. In: CASTRO, P.R.C.; SENA, J.O.A.; KLUGE, R.A. Introdução à fisiologia do desenvolvimento vegetal. Maringá: Eduem, 2002, p.139-158.

NITSCHE, P. R.; CARAMORI, P. H.; RICCE, W. da. S.; PINTO, L. D. F. Atlas climático do estado do Paraná. Londrina: $\quad$ lapar, $2019 . \quad 210 \quad$ p. $\quad$ Disponível $\quad$ em: <http://www.iapar.br/arquivos/File/zip_pdf/AtlasClimaticoPR.pdf>. Acesso em: 08 set. 2020.

OLIVEIRA, F.A.; MEDEIROS, J.F.; ALVES, R.C.; LIMA L.A.; SANTOS, S.T.; RÉGIS, L.R.L. Cowpea beans production in function of salinity and growth regulator. Revista Brasileira de Engenharia Agrícola e Ambiental, v.19, n.11, p. 1049-1056, 2015.

OLIVEIRA, M.G.C.; OLIVEIRA, L.F.C.; WENDLAND, A.; GUIMARÃES, C.M.; QUINTELA, E.D.; BARBOSA, F.R.; CARVALHO, M.C.S.; LOBO JUNIOR, M.; SILVEIRA, P.M. Conhecendo a fenologia do feijoeiro e seus aspectos fitotécnicos. Brasília, DF: Embrapa, 2018. 59p.

OSUGI, A.; SAKAKIBARA, H.Q.A. How do plants respond to cytokinis and what is their importance?. BMC Biology, v. 13, p. 102-112, 2015.

PAVAN, M. A.; BLOCH, M. F.; ZEMPULSKI, H. D. MIYAZAWA, M.; ZOCOLER, D. C. Manual de análise química do solo e controle de qualidade. Londrina, Instituto Agronômico do Paraná,. 1992. 40 p. (IAPAR. Circular, 76).

ROSSI, R. Nitrogênio em cobertura e bioestimulante aplicado via foliar em feijoeiro de inverno no Sistema de plantio direto. 2011. 62 f. Dissertação - Faculdade de Engenharia - UNESP - Campus de Ilha Solteira, São Paulo. 2011.

SANTOS, H.G.; JACOMINE, P.K.T.; ANJOS, L.H.C..; OLIVEIRA, V.A..; LUMBRERAS, J.F.; COELHO, M.R.; ALMEIDA, J.A..; ARAUJO FILHO, J.C..; OLIVEIRA, J.B..; CUNHA, T.J.F. Sistema Brasileiro de classificação de solos. 5 ed. rev. e ampl. Brasília, DF: Embrapa, 2018. 355 p.

SANTOS, V.M.; MELO, A.V.; CARDOSO, D.P.; DA SILVA, Á.R.; BENÍCIO, L.P.F.; FERREIRA, E.A. Development of soybean plants as a function of biostimulant under phosphate fertilization conditions. Bioscience Journal, v. 30, n. 4, p. 1087-1094, 2014.

SANTOS, V.M.; MELO, A.V.; CARDOSO, D.P.; GONÇALVES, A.H.; VARANDA, M.A.F.; TAUBINGER, M. Use of biostimulant in Zea mays L. plant growth. Revista Brasileira de Milho e Sorgo, Sete Lagoas, v. 12, n. 3, p. 307-318, 2013.

SILVA, R.S.; FOGAÇA, J.J.N.L.; MOREIRA, E.S.; PRADO T.R.; VASCONCELOS, R.C. Morphology and common bean production due to the biostimulant. Scientia Plena, v. 12, n.10, p., 2016.

AGROFIT. Sistema de Agrotóxicos Fitossanitários Consulta de Produtos Formulados - Stimulate. Brasília, DF: MAPA. Disponível em: < http://agrofit.agricultura.gov.br/agrofit_cons/principal_agrofit_cons>. Acesso em: 28/02/2019.

SHARMA, H.S.; FLEMING, C.; SELBY, C.; RAO, J.R.; MARTIN, T. Plant biostimulants: a review on the processing of macroalgae and use of extracts for crop management to reduce abiotic and biotic stress. Journal of Applied Phycology, v.26, p. 465-490, 2014.

VANNESTE, S.; FRIML, J. Auxin: A Trigger for Change in Plant Development. Cell, v.136, n.6, p. 1005-1016, 2009. 
VIEIRA, E.L.; MONTEIRO. C.A. Hormônios vegetais. In: CASTRO, P.R.C.; SENA, J.O.A.; KLUGE, R.A. Introdução à fisiologia do desenvolvimento vegetal. Maringá: Eduem, 2002. p.79-104.

VIEIRA, S.M.; RONZELLI JÚNIOR, R.; DAROS, E.; KOEHLER, H.S.; PREVEDELHO, B.M.S. Nitrogen, molybdenum and inoculant for bean crop. Scientia Agraria, v. 1, n. 1-2, p. 63-66, 2000. 